\title{
Andalucía en las Novelas ejemplares de Cervantes: una reflexión sobre el espacio novelesco cervantino
}

\author{
Antonio Rey Hazas*
}

\section{A MODO DE INTRODUCCIÓN}

Decía con toda razón don Francisco Rodríguez Marín que «Cervantes fue [...] un fervoroso enamorado de Andalucía: toda ella, con sus donairosos tipos, con sus escenas animadas, con sus pintorescos lugares, con sus interesantes cuentecillos y tradiciones, alienta, palpita con gran pujanza en las obras del autor de El Ingenioso Hidalgo» ${ }^{1}$. Y así es, sin duda. Pero fue, sobre todo, un enamorado de Sevilla, como demuestran sus Novelas ejemplares (1613), en las que centraré esta investigación. Afirma con razón Rogelio Reyes que:

Sevilla no fue uno más entre los lugares que enhebraron la rica biografía del gran escritor sino una referencia angular en su formación literaria y en su visión del mundo. Por azares de la vida coincidieron y se entrelazaron en el tiempo una ciudad ambivalente, en la cumbre de su poderío y de su esplendor y también de sus miserias, fuente de toda suerte de experiencias, y la más alta personalidad literaria de la historia española, quien extrajo de esa Babilonia hispalense buena parte de la sustancia vital y artística que alimentó su gran talento creador ${ }^{2}$.

No hay que olvidar que nuestro autor, aunque nacido en Alcalá de Henares, era de origen andaluz, cordobés para ser exactos, lo que bien pudo

* Universidad Autónoma de Madrid.

1. Francisco Rodríguez Marín, Perfiles de la Sevilla cervantina. «Discurso preliminar» a la edición de Rinconete y Cortadillo, Sevilla, Ayuntamiento, 1992, pp. 181-182.

2. Rogelio Reyes, «Cervantes y Sevilla: historia de una relación humana y literaria», en Don Quijote en el reino de la fantasía, Fundación Focus Abengoa, Sevilla, 2004, pp. 29-29; en concreto, p. 45. 
influir en su andalucismo. Su abuelo paterno, Juan de Cervantes, nació en Córdoba hacia 1477, se casó con la cordobesa Leonor de Torreblanca en 1504, fue alcalde mayor interino de la ciudad que le vio nacer en $1516 \mathrm{y}$, al año siguiente, teniente corregidor. Su hijo Rodrigo, padre de nuestro autor, que había nacido siete años antes en Alcalá, lo visitó en 1551, durante un par de años, cuando ya el abuelo se había establecido definitivamente en Córdoba, aunque no es probable que Miguel le acompañara. De nuevo regresó Rodrigo a Andalucía, en concreto a Cabra de Córdoba en 1564, dado que allí vivía su hermano Andrés, que era el alcalde mayor. Ese mismo año se halla en Sevilla, acompañado por su hija mayor, Andrea. ¿Viajaría nuestro autor con su padre? Sería tentador suponerlo porque de ese modo se explicaría biográficamente la referencia al colegio sevillano de la Compañía de Jesús que hace Berganza en El coloquio de los perros, donde pudo asistir como alumno el joven Cervantes. Asimismo se iluminaría su recuerdo adolescente de Lope de Rueda, que vivía en el mismo barrio sevillano que habitaban los Cervantes. Pero todo son meras hipótesis sin confirmar.

Lo único cierto es que Cervantes vivió y penó durante trece o catorce años en la Andalucía de finales del siglo XVI, mientras requisaba trigo y aceite para la Invencible o recaudaba impuestos atrasados del reino de Granada, a partir, respectivamente de 1587 y 1594, y al tiempo que sufría sinsabores, procesos judiciales e incluso excomuniones propias de su cargo. Recorrió, pues, los campos andaluces del uno al otro confín y aprendió a conocer y amar a sus gentes, aun a despecho de algunas experiencias duras y conflictivas. Se estableció siempre que pudo en Sevilla, la ciudad de sus amores, a desdén de Córdoba, la patria de sus mayores. Pero amó y sufrió en toda Andalucía, como prueban sus estancias en la cárcel de Castro del Río (1592) y de Sevilla (1597), donde no todo fue negativo, pues nació aquí la idea de escribir el Quijote, concebido por su «padre» o «padrastro», «como quien se engendró en una cárcel».

\section{BREVE CONSIDERACIÓN SOBRE LOS ESPACIOS EN LA OBRA DE CERVANTES}

La prosa de Cervantes se ha valorado desde antaño por su plasticidad, por su espléndida y sugerente reproducción del espacio. Con intuición y saber notables, decía Bergamín, por ejemplo, que:

Si examinamos el lenguaje cervantino, advertiremos enseguida que [...] es extraordinario, milagroso [...] el poder pictórico de su plasticidad imaginativa, visual. Cervantes, y esto es sobrado conocido, lo mismo cuando escribe en prosa que en verso, suele sonar muy mal. El milagro de la palabra cervantina no se verifica en el tiempo, sino en el espacio, luminosamente. Es, por así decirlo, una palabra creadora, la suya, de naturaleza eminentemente visual, teatral, aparente; y aparente con una evidencia reveladora. 
Este plástico mundo novelesco animado por la palabra cervantina, transmutado por el mágico poder de la palabra en un mundo verdadero $[. . .]^{3}$.

Puede afirmarse, a mi entender, que Cervantes utiliza siempre los espacios desde una perspectiva prioritariamente literaria, guiado por las exigencias mismas de cada una de sus obras, y no tanto por los detalles realistas o costumbristas del entorno, válidos en sí mismos, por más que su pluma impar deje en el lector sugerencias, notas y aromas de toda índole. Pero su prioridad literaria no cede nunca: si, por ejemplo, menciona el vino, es para que don Quijote muestre su locura al confundir los cueros con gigantes y el caldo tinto con su sangre; o para que Sancho luzca su afición al vino, a causa de su fino paladar de catavinos o «mojón», y presuma de su ascendencia, al mencionar dos abuelos capaces de discernir incluso sabores a cuero y a hierro en el licor de Baco, porque en la cuba que lo guardaba había una llave y una correa (II, 13); al igual que hace Berrocal en la elección de los alcaldes de Daganzo; o, en fin, para que la vieja Pipota, de Rinconete y Cortadillo, note un cierto sabor a yeso en el vino de Guadalcanal. Se trata siempre, en todo caso, de definir mejor como personajes a don Quijote, a Sancho, a Berrocal y a la vieja Pipota; no tanto de describir el vino y sus cualidades, aunque, como diría Sancho, «vaya arreo». Lope de Vega, en cambio, sí habla del vino en sí mismo, de su elaboración, de sus cualidades, de sus placeres, olores y sabores; incluso se huele el vino en sus escritos por todos lados, hasta el punto de que causa mareo, sueño, incluso amor, en obras llenas de bodegas de verdad, como $E l$ galán de La Membrilla.

Con el espacio sucede lo mismo. Es suficiente recordar cómo se interrelaciona el descenso a la cueva de Montesinos con el ascenso a los cielos de Clavileño, para comprobar que se trata de una cuestión meramente literaria, más allá de cualquier otra consideración sobre el espacio — que también las hay, pero secundarias - El problema es que la bajada a la sima de don Quijote, a quien descuelga su escudero con una cuerda, es puesta en cuestión por el mismo Sancho, que no cree que el caballero hubiera permanecido en la cueva «tres días con sus noches», como asegura el hidalgo, sino, a lo sumo, «media hora» o «una hora» (II, 23). Por eso, cuando más adelante, en el episodio del caballo de madera que sube a las estrellas, el criado habla de haber tocado casi con su mano el mismo cielo y dice haberse apeado en las Siete Cabrillas, don Quijote replica y le dice: «Sancho, pues vos queréis que se os crea lo que habéis visto en el cielo, yo quiero que vos me creáis a mí lo que vi en la cueva de Montesinos. Y no os digo más» (II, 41). El problema principal es la credibilidad de los protagonistas, clave del juego literario que se establece entre ellos y sus lectores. Se trata, a la postre, de una cuestión de verosimilitud.

Pero no hay que olvidar que también es una bajada y una subida, lo que implica un inequívoco equilibrio, una búsqueda de contrapeso, del justo medio

3. José Bergamín, Beltenebros y otros ensayos sobre la literatura española, Barcelona, Noguer, 1973, pp. 94-95. 
entre espacios opuestos, y en consecuencia, lo primordial es finalmente el juego literario con esos espacios, más aún, la búsqueda del sentido mismo de la espacialidad novelesca en ellos, visto así como un entramado de interrelaciones, como algo dinámico, que contrasta y choca, que pugna, por tanto, y busca su equilibrio, como los personajes de la obra. Porque se trata de nivelar literariamente a don Quijote y a Sancho, de ubicarlos en el fiel de la balanza, de igualar espacialmente al amo y al criado, al caballero y al escudero, o de «quijotizar» a uno y de «sanchificar» al otro, si se quiere, como dijera Madariaga ${ }^{4}$, aunque espacialmente, claro está.

De hecho, en La Gitanilla, sin ir más lejos, sucede lo mismo, pues cuando Preciosa va a casa de su enamorado, el caballero don Juan de Cárcamo, este y su familia están situados arriba, en el balcón, como corresponde a su clase social, muy superior, mientras que la gitana y los suyos están abajo, en el lugar de la escala social que les corresponde, a pie de calle, bajo las plantas de los nobles. Sin embargo a continuación, la gitana sube por la escalera a la casa del caballero y este incluso se desmaya (se baja, se pone en línea) mientras ella luce toda su gracia y su discreción ya arriba, en el mismo piso, en el mismo nivel horizontal —y social-: y es que ella acaba de ascender, o mejor dicho, acaba de iniciar su ascenso, que es real, claro está, pues en verdad sube espacial y socialmente, ya que no es el caballero quien baja sino ella quien sube de categoría, como se demuestra al final de la novela, cuando la gitana resulta ser hija de otro caballero. Una vez más, por tanto, los espacios son significativos y están íntimamente ligados a los procesos literarios, en este caso niveladores o igualadores de las respectivas trayectorias novelescas $\mathrm{y}$ vitales de los personajes.

Aunque, como he dicho, también en sí mismos tienen interés los espacios, pues se trata de ascensos que se equilibran con descensos o de ascensos que implican nivelaciones, pero siempre, y es lo importante, el juego tiende a la armonía, al equilibrio o a la sustitución de unos espacios por otros, en el fiel de la balanza.

Tras estas breves consideraciones, que estimo previas e imprescindibles para reflexionar sobre el espacio literario cervantino, paso a analizar el espacio andaluz de las novelas cortas de Miguel de Cervantes.

\section{ANDALUCÍA EN LAS NOVELAS EJEMPLARES. LITERATURA}

Las dos doncellas comienza su acción en «una venta de Castilblanco, a cinco leguas de Sevilla», refiriéndose seguramente a Castilblanco de los Arroyos, porque poco después un caballero toma allí «el camino de Cazalla, donde tenía una rica heredad», lo que demuestra que Cervantes conocía muy bien

4. Salvador de Madariaga, Guía del lector del "Quijote». Ensayo psicológico sobre el "Quijote», Madrid, Espasa-Calpe, 1926. 
el camino que pasaba por Castilblanco e iba a Cazalla de la Sierra, Alanís y Guadalcanal, ya que los tres últimos pueblos sevillanos eran famosos entonces por sus excelentes vinos, hoy desaparecidos, tal y como nos recuerdan varias veces sus obras. Un hidalgo aparece en la venta, y dice venir «del Puerto de Santa María, adonde dejaba cuatro galeras de partida para Nápoles», indicación de que tampoco le era desconocido el pueblo gaditano. Leocadia, en fin, una de las dos doncellas, le cuenta a Teodora, la otra, que salió de su «casa y a pie — dice - caminé algunas leguas y llegué a un lugar que se llama Osuna, y, acomodándome en un carro, de allí a dos días entré en Sevilla: que fue haber entrado en la seguridad posible para no ser hallada, aunque me buscasen». Es decir, que nuestro autor menciona también Osuna, donde había sido corregidor su abuelo Juan años atrás y él había estado poco antes, al menos en sus cercanías, ya en sus requisas de trigo y aceite por Écija, ya en su recogida de alcabalas en Estepa, a tres leguas de Osuna, como demuestran las menciones burlescas a su universidad menor y al propio duque de Osuna, o el hecho de que una de las más celebradas mujeres quijotescas, Dorotea, sea natural de esa zona, por más que confunda Osuna con un puerto de mar ${ }^{5}$. Todo ello, obvio es decirlo, demuestra que Cervantes conocía muy bien la actual provincia sevillana.

Por eso, precisamente, es muy significativo que mantenga en el anonimato los pueblos de origen de las dos doncellas y sus enamorados, cercanos a los que acabo de mencionar. Los protagonistas de la novela, en efecto, proceden de dos lugares, aunque próximos, desconocidos de Andalucía, porque el narrador se niega a revelarlos.

Y eso es fundamental. Se trata de personajes andaluces nobles, sin más precisión. Por eso comienzo mi recorrido del espacio andaluz por esta novela ejemplar, que relata cómo se soluciona felizmente la peripecia amorosa de dos damas enamoradas del mismo caballero, una que ya no es doncella y la otra que ha estado a punto de dejar de serlo, cuando, finalmente, el hermano de una de ellas se enamora de la otra. Lo más interesante del caso es que su andalucismo evidente incluye también un elogio de Cataluña, de Barcelona en concreto, porque es un caballero catalán quien ayuda a los andaluces a solucionar sus problemas en la ciudad condal, lo que la relaciona directamente con el final de la segunda parte del Quijote, seguramente porque todo está escrito por las mismas fechas, donde suceden lances muy similares.

Los estudiosos han visto que el espacio es clave en esta novela: «la materia novelesca - dice Joaquín Casalduero ${ }^{6}$ - se organiza en cuatro partes. Dos ventas, una en Andalucía, cerca de Sevilla, y otra en Cataluña, cerca de Barcelona». Febres, guiado por la misma lógica espacial y, a consecuencia de que hay otros muchos lugares en la narración, prefiere entender que: «la materia novelesca de Las dos doncellas no está organizada en cuatro partes,

5. Vid. F. Márquez Villanueva, «Dorotea, la muchacha de Osuna», Archivo Hispalense (2. ${ }^{a}$ época), XLVI-XLVII (1967), pp. 147-163.

6. Sentido y forma de las Novelas Ejemplares, Madrid, Gredos, 1969, p. 204. 
sino en tres: Andalucía, Cataluña y Andalucía» ${ }^{7}$. En cualquier caso es fundamental la relación entre Andalucía, punto de partida y de regreso, donde se crea el problema de amor y honor, y Barcelona, donde a intervención de don Sancho de Cardona abre la solución de los conflictos. Se trata de un asunto de caballeros y de espacios. Por eso, la magnífica lección de humanismo renacentista que da la novela, su mensaje de tolerancia no se detiene sólo en lo amoroso-matrimonial y en la restauración del honor, sino que, en perfecta coherencia, todavía más allá, afecta por igual a los sentimientos nacionalistas, ligados a espacios diferentes que no sólo no impiden ni obstaculizan, sino que, justo a la inversa, ayudan a la feliz solución de los problemas, como demuestra la decisiva intervención de don Sancho Cardona en el asunto de la obra. Por encima de los impedimentos del rígido código del honor y de las prohibiciones de la moral convencional que obstaculizan el matrimonio de los cuatro protagonistas, por encima de las diferencias de nacionalidad y espacialidad (o de espacios nacionales, si se quiere) que separan a los andaluces del caballero catalán, se impone la generosidad, la tolerancia y la virtud individual de todos ellos, para mostrar que, más allá de la victoria amorosa, la novela es un canto a las cualidades y virtudes individuales de los seres humanos, capaces de superar por sí solas cualquier obstáculo que se les interponga, por dificultoso que sea. La novela, en fin, es una lección de humanismo auténtico y una defensa de los valores del hombre. Por eso cuando todo parece ir de mal en peor, en medio de una batalla, en un lugar «extranjero» - dice el texto, refiriéndose a Barcelona-, con uno herido y los otros amenazados, es precisamente cuando todo se soluciona, gracias a la nobleza generosa de un caballero catalán, gracias a sus valores individuales. Más allá de los espacios disímiles y de las fronteras están los valores del humanismo, están la libertad y la dignidad del hombre. El espacio es, por tanto, solidario de la lección renacentista de tolerancia, sin duda.

El juego con los espacios de Las dos doncellas es de una extraordinaria sutileza artística, porque, a diferencia de tantos lugares sevillanos explícitos y de la polaridad entre Andalucía/Cataluña, los pueblos concretos de las dos protagonistas, sin embargo, se velan y no aparece nunca su nombre. Una de las doncellas dice: «mi nombre es Teodosia; mi patria, un principal lugar desta Andalucía, cuyo nombre callo, porque no os importa a vos tanto el saberlo como a mí el encubrirlo». Al acabar la novela, de vuelta en Andalucía y ya felices todos, Cervantes concluye pidiendo comprensión - con su tolerancia infinita - para las damas y para su pasión amorosa, única responsable de todos los problemas, y explica así por qué no menciona los lugares de origen de sus héroes: «Los cuales luengos y felices años vivieron en compañía de sus esposas, dejando de sí ilustre generación y decendencia, que hasta hoy dura en estos dos lugares, que son de los mejores de la Andalucía, y si no se nombran es por guardar el decoro a las dos doncellas, a quien quizá las lenguas

7. E. J. Febres, «Las dos doncellas: novelización de formas y sentidos múltiples», Anales Cervantinos, XXXI (1993), pp. 75-98; en concreto, p. 78. 
maldicientes o neciamente escrupulosas les harán cargo de la ligereza de sus deseos y del súbito mudar de trajes; a los cuales ruego que no se arrojen a vituperar semejantes libertades, hasta que miren en sí si alguna vez han sido tocados destas que llaman flechas de Cupido, que en efeto es una fuerza, si así se puede llamar, incontrastable, que hace el apetito a la razón».

La honra, pues, tan quebradiza como el vidrio, por la que don Quijote dice a Sancho, junto con la libertad, que «se puede y aun se debe aventurar la vida», es la causa del encubrimiento. El espacio concreto andaluz, pues, desaparece en este caso por imperativos del honor, en beneficio de ambas doncellas y de su fama.

Lo mismo acaecía en el Quijote - con cuya segunda parte, en un momento dado, guarda tantos paralelismos Las dos doncellas a causa del elogio de Barcelona y de la intervención decisiva de los caballeros catalanes que exponen ambas novelas - al decir de Dorotea: «en esta Andalucía hay un lugar de quien toma título un duque, que le hace uno de los que llaman grandes en España. Éste tiene dos hijos: el mayor, heredero de su estado y, al parecer, de sus buenas costumbres; y el menor no sé yo de qué sea heredero, sino de las traiciones de Vellido y de los embustes de Galalón. Deste señor son vasallos mis padres, humildes en linaje [...] labradores, gente llana, sin mezcla de alguna raza mal sonante, $y$, como suele decirse, cristianos viejos ranciosos; pero tan ricos, que su riqueza y magnífico trato les va poco a poco adquiriendo nombre de hidalgos, y aun de caballeros» (I, 28).

El lugar de Dorotea tampoco se dice, pese a que sabemos que es igualmente principal y de Andalucía. Es verdad que se ha identificado con Osuna, villa que se menciona también aquí, por lo que no sé si los dos lugares principales serán Osuna y Estepa, quizá, u otros cuales quiera, iquién sabe! Porque lo importante es que unos y otros permanecen expresa y voluntariamente en el anonimato por razones semejantes, ya que el caso de Dorotea es muy parecido al de nuestras dos doncellas, es también un caso de deshonra femenina que acaba por transformarse en honra y por triunfar, razón que aconseja ocultar el nombre del pueblo, a causa de la deshonra inicial, para no hacerla patente, para mantenerla también en el anonimato, dados los prejuicios socio-morales de la época. Cervantes quiere, en suma, defender la libertad de elección y la honra de la mujer en ambos $\operatorname{casos}^{8}$. Lo importante, en fin, es que unos lugares andaluces se mencionan y otros se ocultan en función de su necesidad literaria, de su pertinencia artística. Tal es la motivación principal.

Pero hay otros usos espaciales distintos en Las dos doncellas, pues un dilatado valle es el espacio elegido para concluir el relato, asimismo sin nombre, aunque de manera muy teatral $\mathrm{Y}$ es que Cervantes quiere llamar la

8. No deja de ser curioso que algunas de las mujeres cervantinas más decididas y valientes en la defensa de su amor sean andaluzas, cuando se trata de damas nobles o ennoblecidas, como la hija de un labrador rico, en el caso de Dorotea. Incluso una cortesana como la protagonista de El vizcaíno fingido, una «sevillana de todo rumbo y manejo», tiene valores muy notables, pese a su condición de prostituta de lujo. 
atención del lector sobre lo que está escribiendo, quiere advertirle de que se encuentra ante algo nuevo, inusual, dado que invierte del orden barroco en el que los padres, como es sabido, deciden e imponen el matrimonio a sus hijos, que suelen enfrentarse a menudo en duelos por honor, de interferencia amatoria, etc. En este caso, sin embargo, sucede justo al revés, los hijos ya han solucionado sus conflictos, y son los padres, significativamente, los que están luchando en duelo por mantener el honor familiar.

Asistimos entonces a «una gran escena teatral con una compleja escenografía. El espacio es abierto: es un ancho valle. Primero sitúa a los observadores, las dos parejas protagonistas, en un recuesto o pendiente para que puedan ver bien lo que nos va a describir. Lo hace a través de lo que ven los personajes. Primero «vieron $[\ldots]$ y [vieron] y de allí a poco vieron $[. .]$.$» . En un segundo$ momento, las dos parejas protagonistas abandonan su lugar de observación y llegan junto a los dos combatientes, a los que con asombro reconocen como sus padres [...]. Pero no acaba aquí lo teatral, porque ellos se convertirán a su vez en objeto de la mirada de una gran cantidad de gente armada que venía a defender al caballero de su lugar [...]. La maestría con que Cervantes cambia el punto de vista es indudable ${ }^{9}$. De este modo, el novelista destaca la escena, la ilumina con una suerte de foco narrativo y teatral que «crea en el lector la ilusión de la representación, y aun más, le da un papel en ella» ${ }^{10}$.

La teatralidad explícita hace que el lector detenga un momento su atención en la importancia del lance y se dé cuenta, así, de que los protagonistas de la narración ya no son los mismos, pues se han convertido momentáneamente en meros espectadores. De esta espacial y trastocada manera, realza la inversión social que está haciendo, dada la condición familiar de la honra, pues los protagonistas se convierten en espectadores, y los espectadores en protagonistas. Después, tras la ruptura momentánea, padres e hijos vuelven a ocupar sus roles habituales: los héroes dejan de ser espectadores, retornan a su lugar, y la novela concluye definitiva y felizmente.

En paralelo y en contraposición, a la par, con el final de Las dos doncellas, la conclusión de La española inglesa, igualmente andaluza e igualmente teatral, acaece sin embargo en un espacio bien conocido e identificado como es Sevilla, y delante de un público muy numeroso: ante lo más granado de la ciudad, para ser exactos. Es decir, en las antípodas andaluzas de un ámbito reducido, meramente familiar, y campesino, como el de las Doncellas. En consecuencia, son dos finales tan iguales por su teatralidad y por su diseño espacial de escena pública, como opuestos por los espacios concretos en que acaecen. Isabela ya es famosa en Sevilla, su extraordinario caso lo conoce toda la ciudad, y por eso está presente a las puertas de un convento bien conocido también, sabedora de que entonces tiene lugar entrada de la heroína como novicia en el monasterio de Santa Paula:

9. Como ha estudiado Rosa Navarro, «Gestos y escenas en las Novelas Ejemplares», Anuari de Filologia, XVII (1994), pp. 101-114; en concreto, p. 111.

10. Ibíd., p. 114. 
[...] pasóse el término de los dos años y llegóse el día de tomar el hábito, cuya nueva se estendió por la ciudad; y de los que conocían de vista a Isabela, y de aquéllos que por sola su fama, se llenó el monasterio y la poca distancia que dél a la casa de Isabela había. Y, convidando su padre a sus amigos y aquéllos a otros, hicieron a Isabela uno de los más honrados acompañamientos que en semejantes actos se había visto en Sevilla. Hallóse en él el asistente y el provisor de la Iglesia y vicario del arzobispo, con todas las señoras y señores de título que había en la ciudad: tal era el deseo que en todos había de ver el sol de la hermosura de Isabela, que tantos meses se les había eclipsado. [...] El concurso de la gente fue tanto, que les pesó de no haber entrado en los coches, que no les daban lugar de llegar al monasterio. Unos bendecían a sus padres, otros al cielo, que de tanta hermosura la había dotado; unos se empinaban por verla; otros, habiéndola visto una vez, corrían adelante por verla otra. [...] Todas estas razones oyeron los circunstantes, y el asistente, y vicario, y provisor del arzobispo; y de oírlas se admiraron y suspendieron, y quisieron que luego se les dijese qué historia era aquélla, qué estranjero aquél, y de qué casamiento trataban.

Se trata de un final completamente teatral y público, en los accesos concretos al monasterio real de Santa Paula, con toda Sevilla como espectadora de tan peregrinos lances. Pero opuesto en lo demás al de Las dos doncellas. No se olvide: el equilibro espacial siempre aparece, más tarde o más temprano, en el conjunto de la obra cervantina.

La novela armoniza ahora España e Inglaterra, dos países enemigos, o dos espacios enfrentados, si se quiere, que acaban por conjuntarse, gracias al amor más puro y espiritualizado y a la común religión católica de la española y el inglés. No obstante, y por lo que a Andalucía se refiere, la novela comienza en Cádiz y acaba en Sevilla, y es sin duda mucho más sevillana que gaditana, pues Gadir se ve siempre desde Hispalis. Es la misma óptica del famoso soneto burlesco de 1596, que se ríe de la fanfarria aparatosa del ejército español («cofradías/que los soldados llaman compañías,/de quien el vulgo y no el inglés se espanta»), que acude al socorro de Cádiz desde Sevilla con mucha parsimonia, «con mesura harta», y llega tarde, como es lógico, «ido el inglés», después de haber saqueado la ciudad impunemente durante 24 días. Entonces, magna ironía, «triunfante entró el gran duque de Medina». La novela parte del mismo saqueo, pero, tras numerosos lances, acaba en Sevilla, donde todo se equilibra, y desde donde todo se ve. Es, por tanto, en términos de espacio andaluz, Cádiz vista desde Sevilla, aunque muy en lontananza, pues la capital hispalense predomina por completo. Da la sensación de que, para Cervantes, Sevilla se olvida un poco de Cádiz. Quizá la desdeña, quizá la teme, o ambas cosas, sabedora de que acabará por hacerse con el monopolio de la flota y del mercado americano que detenta la Roma andaluza. La mirada del sevillano Miguel de Cervantes no oculta nunca nada. Al final, os vinos de Jerez, el Puerto y Sanlúcar desbancarán a los de la Sierra de Sevilla, a los de Cazalla y Alanís, que acabarán o desaparecer. Sevilla y Cádiz entonces competían. La mirada atenta de Cervantes lo percibió, literariamente, a su manera. Y es, 
no lo olvidemos, la Sevilla pública, la que ahora se erige en espectadora de unos extraños sucesos de amor y religión, pues lo privado se ve y se comenta siempre en público.

Tras los andaluces caballerescos y nobles, tras los hombres de honor y las mujeres principales enamoradas, tras la española y el inglés, lejos de la ciudad del Betis, aparecen dos estudiantes ricos que regresan a Andalucía desde la Universidad de Salamanca y se llevan con ellos a su criado, Tomás Rodaja, el futuro Licenciado Vidriera: «Sucedió que se llegó el tiempo que sus amos acabaron sus estudios y se fueron a su lugar, que era una de las mejores ciudades de la Andalucía». Pronto, sin embargo, a diferencia de Las dos doncellas, la menciona, pues se despide de sus amos y sale, dice, «de Málaga (que ésta era la patria de sus señores); y, al bajar de la cuesta de la Zambra, camino de Antequera», encuentra «un gentilhombre a caballo», que resulta ser «capitán de infantería», a quien se une y con quien llega «aquella noche a Antequera». El capitán se llama Diego Valdivia, y no sé si el nombre tiene alguna relación con el licenciado del mismo nombre, Alcalde de la Audiencia de los Grados, en Sevilla, que encargó alguna requisa a Miguel de Cervantes. Aunque sí sé que no vuelve a aparecer más Andalucía en la mencionada novela cervantina, y que la referencia a Málaga es de primera mano y demuestra que Cervantes conocía bien, en todo caso, el camino de Antequera, por haberlo hecho personalmente en alguna ocasión, mientras ejercía su cargo de recaudador de impuestos impagados en el reino de Granada.

No tiene más importancia Andalucía en La ilustre fregona, aunque sí abre el camino de la picaresca andaluza, dado que Carriazo inicia su aventura en «las almadrabas de Zahara, donde es el finibusterrae de la picaresca», porque nadie puede llamarse pícaro que no haya «cursado dos cursos en la academia de la pesca de los atunes». El personaje, sin embargo, regresa a Burgos y aunque pretende volver en compañía de su amigo Avendaño a las almadrabas gaditanas, se queda en Toledo, al prendarse su amigo de Constanza, la hermosa y honesta fregona del mesón del Sevillano.

No obstante, a juzgar por lo que dice el Padre León en su interesantísimo Compendio de 1619, es cierto lo que dice Cervantes, que en consecuencia debía de conocer bien la zona de la pesca del atún, desde Gibraltar hasta Vejer, pues los pescadores, en efecto, «no parecen sino caribes, forajidos y bandoleros». Todos eran «facinerosos, valentones y forajidos, que iban a hacer de las suyas en aquella temporada, a donde, a río revuelto, como se suele decir, tiene el demonio, maldito pescador de almas, sus ganancias muy ciertas, porque allí estaban sus amiguillas, y por quítame allá esa paja se mataban y herían algunas veces» ${ }^{11}$.

Incluso la idea medular de la novela cervantina puede proceder de la realidad de las almadrabas de Zahara, pues dice Herrera Puga que «un tipo muy

11. Apud, Pedro Herrera Puga, Sociedad y delincuencia en el Siglo de Oro, Madrid, BAC, 1974, pp. 340 y 341 . 
original de estos lugares fue el pícaro procedente de la nobleza. Nadie pudiera creerlo, pero, aunque resulte extraño, se dieron casos de hijos de nobles que, atraídos por aquel ambiente, llegaron dispuestos a adaptarse en todo a la vida y costumbres de la picaresca allí reinante». Expresamente lo dice León, después de haber tenido varios encuentros con «hijos de gente principal»: «[...] Con la misma facilidad que se les despedía, con mayor aún volvían a aparecer, atraídos sin duda por el sabor picaresco de la tierra [...]». Sin duda, estos casos tienen su interés particular, pero lo más notable es que fueron bastante frecuentes. En distintas ocasiones se presentó allí el hijo de un conde de España. Varias veces lo devolvieron a su padre, y otras tantas volvió a aparecer. Tanta insistencia no era fácil comprenderla, y así, después de cierto diálogo, manifestó que su única pretensión era «ser pícaro», como otros muchos que vivían en aquella región. Sin duda que estos ejemplos fueron los que le dieron al padre León el fundamento para bautizar a esta región como «refugio de pícaros», y a Cervantes, con el título de «cátedra de la picaresca» ${ }^{12}$.

\section{SEVILla EN LAS NOVELAS EJEMPLARES. LiteraturA ${ }^{13}$}

Hay siete novelas ejemplares que tienen relación con Andalucía. Tres de las cuatro novelas ya consideradas pasan fugazmente por la costa de Cádiz y Málaga, o parten y regresan a lugares no identificados de Andalucía. La cuarta, La española inglesa, pese a su carácter viajero y bizantino, que la lleva al Atlántico y al Mediterráneo, a Inglaterra y a Roma o Argel, es ya bastante sevillana, por su final público espléndido, que tanta fortuna ha tenido en las letras españolas. Menos, y reducida al ámbito rural de las proximidades de Sevilla, como hemos visto, es el espacio de Las dos doncellas. En las dos

12. Ibíd., p. 344.

13. Sevilla es sin duda la ciudad que más aparece y se menciona en la obra de Cervantes. Su bibliografía es ya numerosa, y el mejor de todos los libros, a lo que creo, y el más bello, asimismo, sobre esta relación axial, es el de Rogelio Reyes y Pedro Piñero, Itinerario de la Sevilla de Cervantes, Sevilla, 2005. También es inexcusable, Francisco Márquez Villanueva, «Sevilla y Cervantes una vez más», en Cervantes en letra viva, Barcelona, Reverso, pp. 129-150. Asimismo merecen mención G. Albarrán Puente, «La Sevilla que vio Cervantes», AC, VIII (1960), pp. 321-3555; Héctor Brioso Santos, Sevilla en la literatura del Siglo de Oro: el sentimiento anticiudadano barroco, Sevilla, Ayuntamiento, 1998, e ídem, Sevilla en la prosa de ficción del Siglo de Oro, Sevilla, Diputación, 1998; J. M. Caballero Bonald, Sevilla en tiempos de Cervantes, Barcelona, Planeta, 2003; Marco Cipolloni, «Roma triunfante en ánimo y nobleza. Sevilla como teatro de la ironía política cervantina», en Cervantes y Andalucia: biografia, escritura, recepción; P. Ruiz, Estepa, 1999, pp. 164-172; Juan Lamillar y Maribel Cruzado, Cervantes y Sevilla. Guía del visitante, Sevilla, Caja San Fernando, 2005; Luis Larroque Allende, «Las actividades económicas de Cervantes en Andalucía», en Cervantes y Andalucía: biografia, escritura, recepción; P. Ruiz, Estepa, 1999, pp. 113-125; Luis Montoto, De Cervantes y Sevilla. Crónica 1616-1916, Sevilla, 1916; Pedro Piñero, Sevilla en el imperio de Carlos V, Sevilla, Universidad; F. Rodríguez Marín, El Loaysa de «El celoso extremeño»: estudio histórico-literario, Sevilla, 1901; «La cárcel en que se engendró el Quijote», en AA. VV., Álbum cervantino, Sevilla, Ateneo, 2002; Rinconete y Cortadillo, Sevilla, 1905; J. Santos Torres, «Cervantes y la justicia sevillana», en Cervantes y Andalucía: biografia, escritura, recepción; P. Ruiz, Estepa, 1999, pp. 126-142. 
restantes, El licenciado Vidriera y La ilustre fregona, la acción principal no sucede nunca al sur de Despeñaperros. Sin embargo, hay otras cuatro novelas, incluida La española, mucho más centradas en el espacio andaluz, concretamente en el sevillano, dado que, o bien acaecen fundamentalmente en Sevilla (Rinconete y Cortadillo, El celoso extremeño), o bien concluyen su peripecia en dicha ciudad (La española inglesa), o bien comienzan su andadura en ella (El coloquio de los perros). Todas se distinguen, en consecuencia, por su axial espacio sevillano.

A diferencia radical de la Sevilla pública y oficial de La española inglesa, la de Rinconete y el Coloquio de los perros es secreta y oculta, es el ámbito de los delincuentes confabulados con la justicia. Berganza es un perro sevillano que asiste desde pequeño a toda suerte de ilegalidades, desde los matarifes que se quedan con la mejor parte de la carne para regalársela a sus queridas, hasta los esclavos negros que engañan a sus amos o los pastores que matan las ovejas y echan la culpa a los lobos. Sólo se libran los abnegados profesores jesuitas, lo que ha hecho suponer que Cervantes estudió con ellos. La novela también visita otros lugares de Andalucía, y concretamente en Montilla tiene lugar un episodio decisivo, el de la bruja Cañizares. Pero lo importante es que Sevilla es aquí la misma ciudad del hampa en la que aún quedaban tres espacios ajenos a la autoridad del rey: «la calle de la Caza, la Costanilla y el Matadero»; la misma ciudad de Monipodio, el cuasi capo de la mafia que aparece en Rinconete y vuelve a reaparecer aquí, en un mundo novelesco moderno, casi actual, que va más allá de una sola novela, como en Balzac o Galdós: «Finalmente — dice el perro hablador_- vine a entender con toda certeza que el dueño de la casa, a quien llamaban Monipodio, era encubridor de ladrones y pala de rufianes, y que la gran pendencia de mi amo había sido primero concertada con ellos»».

Nada tiene de extraño que en el pasado, cuando apenas existían datos biográficos fiables, algún erudito llegase incluso a pensar que nuestro autor había nacido en Sevilla. Me refiero a nuestro primer gran bibliógrafo, Nicolás Antonio, para quien Cervantes era natural de Hispalis. Aunque ya Mayans echó por tierra la hipótesis sevillana en su Vida de Miguel de Cervantes (1738), usando con rigor inapelable la lógica más estricta. Oigamos sus palabras:

El gran émulo de Tamayo, don Nicolás Antonio, patrocina la causa de Sevilla y, para probarla, alega dos razones o conjeturas. Dice que Cervantes, siendo niño, vio representar en Sevilla a Lope de Rueda, y añade que los apellidos de Cervantes y Saavedra son sevillanos. La primera conjetura prueba poco. Yo, siendo niño, vi representar en el Teatro de Valencia un gran comedión (que es el único que he visto) y no soy de Valencia, sino de Oliva. Fuera de esto, diciendo Cervantes que «Lope de Rueda, varón insigne en la representación y en el entendimiento, fue natural de Sevilla», era natural también llamarla su patria; y ni en ese ni en otros lugares donde nombró a Sevilla, la reconoció como tal. La segunda conjetura aún prueba menos: porque si Miguel de Cervantes Saavedra hubiera sido de los Cervantes y Saavedra de Sevilla, siendo nobles estas familias, lo hubiera él 
apuntado en alguna parte hablando en tantas de sí, y lo más que dijo fue ser hidalgo sin añadir circunstancia que indicase su solar, $y$, a ser natural de Sevilla, en las mismas familias sevillanas de Cervantes y Saavedra se hubiera conservado desde aquel tiempo la gloriosa memoria de haber dado a España tan ilustre varón. Prueba que hubiera alegado don Nicolás Antonio, siendo de esta opinión y natural de Sevilla ${ }^{14}$.

Decía, sin embargo, con toda razón Rodríguez Marín que «hispalense fue, por el alma y por la educación, el gran Cervantes. En Sevilla [...] aprendió, escuchando la rica habla de la gente vulgar, los vocablos más expresivos y eficaces, los giros más geniales de nuestra raza, las imágenes pintorescas y los gallardos modismos, de que tiene Andalucía, en inagotables filones, cien Potosíes, y especialmente las cómicas y garridas hipérboles» ${ }^{15}$. Su mundo literario así parece confirmarlo, porque es hondamente sevillano, como ha visto también Rogelio Reyes: «la dura prueba de la cárcel real; el conocimiento del abigarrado mundo de tahúres, ladrones y pícaros; el alegre vitalismo y la desenvuelta sensibilidad artística de las capas populares de Sevilla, que fueron en verdad las grandes protagonistas de sus obras; sus posibles contactos con el mundo del teatro y las academias [...], todo tuvo que contribuir en no escasa medida a estimular su prodigioso universo narrativo, pródigo en escenas de auténtico «realismo social», de sucesos callejeros, de atractivos personajes y de pintorescos y dramáticos lances protagonizados por la más variada fauna humana destilada por la gran ciudad, cuya riqueza vital no podía pasar inadvertida a su penetrante lucidez, a su proverbial compresión y a su hondo sentido de la solidaridad» ${ }^{16}$.

Cervantes amaba Sevilla, sin duda, y aprendió mucho allí, donde vivió, amó, negoció, ganó dinero, disfrutó, se arruinó y estuvo en prisión; allí donde observó y experimentó un mundo apasionante. Pero Cervantes no era un escritor costumbrista, como ya he dicho, y aunque se inspiró en la ciudad del Guadalquivir y en sus gentes, no copió ni reflejó en sentido estricto, fotográficamente, «como tantas veces se repite, la realidad ambiental» de la ciudad, por la sencilla razón, como bien dice Márquez Villanueva, de que «no es ésta más que materia amorfa que no existe ni nadie ve hasta el momento de ser organizada y puesta en pie por el espejo sthendaliano del novelista. Y este no es a su vez ningún cristal azogado, sino una metáfora, [...] un milagro, si se quiere, pero endeudado con la búsqueda y con la reflexión laboriosa, y no con hallazgos llovidos del cielo» ${ }^{17}$.

Qué duda cabe de que Cervantes, por ejemplo, bien pudo conocer en Sevilla pícaros como los que reflejan las Quintillas de la Heria, o los propios

14. Cito por nuestra edición, Antonio Rey Hazas y Juan Ramón Muñoz Sánchez, El nacimiento del cervantismo: Cervantes y el Quijote en el Siglo XVIII, Madrid, Verbum, 2006, p. 95.

15. Perfiles de la Sevilla cervantina, p. 122.

16. «Cervantes y Sevilla: historia de una relación humana y literaria», en Don Quijote en el reino de la fantasía, Fundación Focus Abengoa, Sevilla, 2004, pp. 45-46.

17. Francisco Márquez Villanueva, «Sevilla y Cervantes una vez más», en Cervantes en letra viva, Barcelona, Reverso, pp. 129-150; en concreto, pp. 142-143. 
versos, que reprodujo Rodríguez Marín, y que la pelea de Rinconete entre el Repolido y la Cariharta, por cuya causa están a punto de sacar las espadas el mencionado valentón, Maniferro y Chiquiznaque, es parecida a la que tiene lugar entre la Acevedo y Ranchal, pues: «aunque la tenía afición,/dio a la marca un bofetón,/que se oyó en el golpe el eco./Y viéndose así agraviada,/ alzó la marquiza el garlo,/y a su voz desentonada/acudió un chulo a vengarlo,/ ya puesta en carnes la espada./Afirmóse con Ranchal,/pero Ranchal, presto y listo,/arrojándole el puñal/le envió a cenar con Cristo». Aunque la pelea es real y se consuma, sus móviles son semejantes, por lo que la inspiración del lance bien puede estar aquí o en otros casos similares. Pero lo importante es que la interpretación de Sevilla que hace Rinconete no reside en el localismo de episodios como éste, sino en el conjunto de la construcción novelesca. Como dice Márquez Villanueva:

Sevilla no es [en la obra cervantina centrada en ella] un pasivo escenario, sino un factor determinante dotado de una sutil caracterización previa que confiere a la ciudad un valor de representatividad asimilable al de un personaje protagonista ${ }^{18}$.

Es el precedente, dice este estudioso, del París de Balzac, el Madrid de Galdós, el San Petersburgo de Dostoievsky, el Dublín de Joyce, la Praga de Kafka, etc., mucho más, pues, que el reflejo costumbrista de la Sevilla áurea. Por consiguiente, es una interpretación magnífica y polifacética de esa misma ciudad a finales del siglo XVI.

El alguacil a quien servía Berganza estaba de acuerdo con los ladrones, como sucede en Rinconete y Cortadillo, seguramente la novela clave para ver cómo era la percepción cervantina de Sevilla. El caso es que dos picaruelos castellanos llegan a la ciudad, realizan algún que otro hurto, y de pronto les dicen que en Sevilla hay que pagar impuestos para robar. Los picarillos no lo entienden, como tampoco entienden el lenguaje de germanías en que les hablan:

—Díganme, señores galanes: ¿voacedes son de mala entrada [ladrones], o no?

— No entendemos esa razón, señor galán — respondió Rincón.

- ¿Qué no entrevan, señores murcios? [¿qué no entienden, señores ladrones?] — respondió el otro.

— Ni somos de Teba ni de Murcia — dijo Cortado-. Si otra cosa quiere, dígala; si no, váyase con Dios.

— ¿No lo entienden? — dijo el mozo—. Pues yo se lo daré a entender, y a beber, con una cuchara de plata: quiero decir, señores, si son vuesas mercedes ladrones. Mas no sé para qué les pregunto esto, pues sé ya que lo son. Mas díganme: ¿cómo no han ido a la aduana del señor Monipodio? — ¿Págase en esta tierra almojarifazgo [impuesto] de ladrones, señor galán? —dijo Rincón. 
— Si no se paga — respondió el mozo-, a lo menos regístranse ante el señor Monipodio, que es su padre, su maestro y su amparo; y así, les aconsejo que vengan conmigo a darle la obediencia, o si no, no se atrevan a hurtar sin su señal [permiso], que les costará caro.

- Yo pensé — dijo Cortado - que el hurtar era oficio libre, horro de pecho y alcabala [libre de impuestos].

Este es el verdadero andalucismo de nuestro novelista. Cervantes ofrece así las claves: dentro de Sevilla, la ciudad más grande de la España áurea, con unos 135.000 habitantes a finales del XVI, hay otra ciudad, otro mundo pequeño, secreto y oculto, para acceder al cual es necesario atravesar literalmente una frontera, como si de otro país se tratase: porque en verdad es otro país, dado que la cofradía de Monipodio tiene sus propias leyes, su jefe, sus grados y escalas jerárquicas, sus particulares impuestos — «almojarifazgo de ladrones» - e incluso su peculiar y diferente idioma: el lenguaje de germanías. La gran ciudad, pues, oculta otra ciudad diferente dentro de ella, pues tiene incluso fronteras interiores bien marcadas, como Rincón y Cortado comprueban de inmediato, cuando acceden al patio de Monipodio y el resto de la ciudad desaparece de la novela, que ya no sale nunca de ese recinto cerrado, hasta que los picarillos deciden, al final, abandonarlo. Es, pues, un mundo completo y aparte. Más aún, los rufianes y jaques de Monipodio piensan incluso salvar su alma e ir al cielo, pese a sus muchos crímenes y delitos, a causa de su religiosidad meramente externa, cercana a la idolatría: son ladrones, dicen «para servir a Dios y a las buenas gentes». Obviamente, es otro mundo, distinto y separado, pero no completamente ajeno, pues implica una parodia y una crítica de los comportamientos del mundo oficial y real de la Sevilla y la España del siglo XVII.

Esta visión cervantina va mucho más allá de la Sevilla de las dos caras diferentes que ha visto la crítica, la Sevilla «grandiosa y brillante, derivada del esplendor mercantil que por entonces vivía; y otra mísera, corrupta y sórdida, consecuencia del submundo que toda ciudad populosa y próspera generaba entonces como ahora» ${ }^{19}$. Porque, como ya vio Héctor Brioso, esa ciudad de cara y cruz, de haz y envés es común a otros muchos escritores del Siglo de Oro y, en mi opinión, podría generalizarse a cualquier otra ciudad grande de la época, como a Madrid, pongo por caso. Y no se trata de eso, a lo que creo, sino de que dentro de Sevilla hay fronteras que apenas se pueden cruzar, aduanas lingüísticas, impuestos diferentes, mundos cerrados casi herméticos, comportamientos distintos, incluso credos contrapuestos, que separan, dividen, marcan territorios autónomos, aíslan zonas; y todo ello, a mayor asombro, a mayor admiración verosimilizada, como le gustaba decir a Cervantes, «mostrar con propiedad un desatino», repito, dentro de la misma ciudad, en el mismo espacio, con los mismos seres, en las mismas calles y plazas. Son

19. Por decirlo con palabras de Rogelio Reyes, art. cit., p. 36. 
varias ciudades en una; varios espacios disimiles e interrelacionados en una ciudad poliédrica, variopinta y multiespacial.

Así las cosas, desde esta visión del espacio sevillano de Rinconete, la novela resulta ser el contrapunto de la Sevilla pública, oficial, honorable y auténticamente religiosa de La española inglesa, por ejemplo; y lo contrario, desde otra óptica, de las fronteras reales, auténticas, que separan Castilla de Cataluña en Las dos doncellas, dado que esta frontera real no sólo no divide, sino que une, al ser un caballero catalán el que acoge y soluciona los problemas de los andaluces. Así pues, el sentido debe tener en cuenta que hay fronteras reales que unen países o naciones diferentes, más que separarlas, junto fronteras dentro de la misma ciudad, dentro de Sevilla, que separan a sus habitantes y encierran el mundo oculto de una suerte de mafia delictiva, al mismo tiempo que su errónea interpretación de la fe religiosa, reducida a mera idolatría de imágenes, realza la pureza religiosa auténtica y honrosa de la vida pública y oficial de la gran Sevilla que encarna claramente, por ejemplo, La española inglesa. Y es que no hay dos caras, ni dos Sevillas, sino muchas, varias, múltiples y polifacéticas. Tal es la grandeza del arte cervantino, auténticamente literaria, genialmente estética, porque el paso de la frontera supone, además, el de la novela picaresca al entremés de jaques, el de un género literario a otro, a mayor gloria de su creador ${ }^{20}$.

Vista la utilización novelesca del espacio sevillano que hace Cervantes, aunque tiene mucho interés conocer la mafia delictiva sevillana cuya existencia real corrobora La Miscelánea, de Luis Zapata, escrita entre 1592 y 1595, porque es muy probable que nuestro autor la conociera, no es determinante, ni mucho menos, dado que no se limita a copiar su existencia. Con todo, recordemos las palabras de Zapata:

En Sevilla dicen que hay cofradía de ladrones con su prior y cónsules como mercaderes; hay depositario entre ellos, en cuya casa se recogen los hurtos, y arca de tres llaves, donde se echa lo que se hurta, y lo que se vende, y sacan de allí para el gasto y para cohechar los que pueden para su remedio. Cuando se ven en aprieto son muy recatados en recibir que sean hombres esforzados y ligeros, cristianos viejos. No acogen sino a criados de hombres poderosos y favorecidos en la ciudad, ministros de justicia; y lo primero que juran es esto, que aunque los hagan cuartos, pasarán su trabajo, mas no descubrirán los compañeros; y ansí, cuando entre gente honrada de una casa falta algo, que dicen que el diablo lo llevó, levántanselo al diablo que no lo llevó, sino alguno de estos. Y de haber la cofradía es cierto, y durará mucho más que la Señoría de Venecia, porque, aunque la justicia entresaca algunos desdichados, nunca ha llegado al cabo de la hebra ${ }^{21}$.

20. Como vieron Domingo Ynduráin, «Rinconete y Cortadillo. De entremés a novela», BRAE, XLVI (1966), pp. 321-333; José Luis Varela, «Realismo cervantino en Rinconete», en La transfiguración literaria, Madrid, Prensa Española, 1970, pp. 53-89.

21. Ed. del Memorial Histórico español, tomo XI, Madrid, 1859, pp. 49-50. 
«Sevilla — dice Márquez - era una ciudad feliz. La prosperidad y el alegre desenfado con que allí pasaban los días carecía de paralelo en España ni fuera de ella. Su mismo endémico desgobierno redundaba en fomentar a fin de cuentas la joie de vivre de sus habitantes, lo cual es, como sabemos, un tema crucial de la novela de Rinconete y Cortadillo». En efecto, uno de los rasgos que mejor define a la novela y más ha llamado la atención de los estudiosos es la alegría que preside siempre su desarrollo, a pesar de la aberración social y moral que caracteriza a los miembros de la hermandad delictiva sevillana. Ya Menéndez Pelayo lo señaló: «corre por las páginas de Rinconete una intensa alegría — dijo 22 - un regocijo luminoso, una especie de indulgencia estética, que depura todo lo que hay de feo y de criminal en el modelo, y sin mengua de la Moral lo convierte en espectáculo divertido y chistoso». Amezúa, tras los pasos del ilustre polígrafo, alabó: «el milagro estético de transformar y ennoblecer a seres moralmente repugnantes, que vegetaban encenagados en la deshonestidad y el ladronicio, despojándoles de sus lacras morales para infundir en ellos como una luz interior, la del Arte, que todo lo limpia, mundifica y sublima» ${ }^{23}$. Casalduero dedicó incluso un capítulo a «la alegría de Rinconete». No se trata, sin embargo, de ningún «milagro estético» ni de alegría en sentido estricto, sino de la utilización de uno de los recursos más característicos de la narrativa cervantina: la ironía. Y es que Cervantes, a diferencia de Alemán, no tiene la visión triste y tétrica de los ascetas sobre el pecado, sino una perspectiva irónica, que se distancia y se ríe con humorismo crítico del reino de paradoja en que viven los cofrades de Monipodio ${ }^{24}$; «Cervantes, en contraste con Alémán, no moraliza: derrama, como Rincón y Cortado al final de la obra, una indulgente sonrisa, mientras se aleja. Esta sonrisa se mantiene a lo largo de toda la narración [...] Se trata de la fluida ironía cervantina, o lo que es lo mismo, de distancia artística ante sus criaturas $»^{25}$.

Ironía y distanciamiento, en efecto, que se logran, entre otros procedimientos, merced a la estructura enmarcada de la novela, que permite el perspectivismo crítico, la mirada nueva, diferente, desde fuera, del insólito sindicato de ladrones de Sevilla. Por ello Rinconete y Cortadillo son superiores a lo cofrades y ajenos a ese mundo cerrado, para que su enfoque pueda ser irónico y crítico. Como vio Casalduero: «a pesar del porte y la faz de Monipodio, a pesar de los bravos, tenemos la sensación de hallarnos en un

22. "Cultura literaria de Miguel de Cervantes y elaboración del Quijote», en Estudios de crítica histórica y literaria, I, p. 339, vol. IV de la E. N. de Santander, 1941.

23. Cervantes creador, II, p. 109.

24. Vid., sobre la ironía en Rinconete, Karl-Ludwig Selig, «Cervantes y su arte de la novela», en Actas del II Congreso Internacional de Hispanistas, Nimega, 1967, pp. 585-590; y R. L. Predmore, «Rinconete y Cortadillo: realismo, carácter picaresco, alegría», Insula, 23 (1968), pp. 17-18.

25. Por expresarlo con términos de J. L. Varela, art. cit., pp. 74-75. Sobre Cervantes y Alemán, vid. F. Márquez, «La interacción Alemán-Cervantes», en Actas del II Coloquio de la AC, Barcelona, Anthropos, 1991, pp. 149-181, y A. Rey Hazas, «El Guzmán de Alfarache y las innovaciones de Cervantes», en Atalayas del Guzmán de Alfarache. Seminario Internacional sobre Mateo Alemán. IV Centenario de la publicación del Guzmán de Alfarache (1599-1999), ed. de Pedro Piñero, Universidad de Sevilla, 2002, pp. 177-217. 
mundo infantil, en un juego, en que la puerilidad de los jugadores les impide ver el engaño» ${ }^{26}$.

Sevilla era para Cervantes un mundo en pequeño, un orbe abreviado, pues como decía Lope de Vega en El arenal de Sevilla: «sola tu maravilla/de todas [las tierras] tiene el valor» (III, 25-29). Era un ámbito contradictorio, a la vez cerrado y abierto, peligroso y festivo, delictivo y alegre, censurable y elogiable. Aunque lo más atractivo de la visión cervantina sea, quizá, la interacción entre los diversos espacios de la urbe, entre las diversas y contradictorias Sevillas que configuran su Sevilla.

Sevilla, como gran ciudad, era el lugar apropiado para alguien que quisiera ocultarse y pasar desapercibido, como bien dice una de las heroínas de Las dos doncellas: «y, acomodándome en un carro, de allí a dos días entré en Sevilla: que fue haber entrado en la seguridad posible para no ser hallada, aunque me buscasen». También Clemente, el paje de La Gitanilla, pensaba escapar de la justicia camino de Sevilla, aunque finalmente no lo hace, porque tampoco los gitanos van a la ciudad andaluza, a causa de los problemas que allí había tenido la abuela de Preciosa con «un gorrero llamado Triguillos». Pero el paje expresa claramente su voluntad de ir a Sevilla: «-El que yo pensaba llevar - replicó el mozo - no es sino a Sevilla; que allí tengo un caballero ginovés grande amigo del conde mi pariente, que suele enviar a Génova gran cantidad de plata, y llevo disignio que me acomode con los que la suelen llevar, como uno dellos, y con esta estratagema seguramente podré pasar hasta Cartagena, y de allí a Italia, porque han de venir dos galeras muy presto a embarcar esta plata. Esta es, buen amigo, mi historia: mirad si puedo decir que nace más de desgracia pura que de amores aguados. Pero si estos señores gitanos quisiesen llevarme en su compañía hasta Sevilla, si es que van allá, yo se lo pagaría muy bien; que me doy a entender que en su compañía iría más seguro, y no con el temor que llevo». Lope de Vega pensaba, asimismo, que era un lugar idóneo para ocultarse y huir de la justicia, a causa de la enorme confusión de la abigarrada ciudad del Guadalquivir:

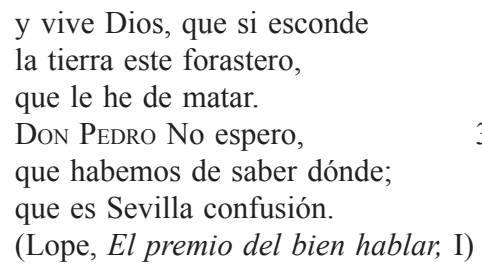

Sin embargo, esa misma facilidad para aislarse y mantenerse en secreto podía ocasionar el efecto contrario, e impedir la ocultación, ya que un exceso de apartamiento o de retraimiento podía llamar la atención de los muchos ojos ociosos que había en la urbe, tal y como le sucede a la recatada y religiosa protagonista de La española inglesa, cuya apartada vida se convierte en atrac- 
ción pública a causa, paradójicamente, de su mismo apartamiento. Oigamos las significativas palabras de Cervantes sobre el particular:

\begin{abstract}
Pocas o ninguna vez salía de su casa, sino para el monasterio; no ganaba otros jubileos que aquellos que en el monasterio se ganaban. Desde su casa y desde su oratorio andaba con el pensamiento los viernes de Cuaresma la santísima estación de la cruz, y los siete venideros del Espíritu Santo. Jamás visitó el río, ni pasó a Triana, ni vio el común regocijo en el campo de Tablada y puerta de Jerez el día, si le hace claro, de San Sebastián, celebrado de tanta gente que apenas se puede reducir a número. Finalmente, no vio regocijo público ni otra fiesta en Sevilla: todo lo libraba en su recogimiento y en sus oraciones y buenos deseos, esperando a Ricaredo. Este su grande retraimiento tenía abrasados y encendidos los deseos no sólo de los pisaverdes del barrio, sino de todos aquellos que una vez la hubiesen visto: de aquí nacieron músicas de noche en su calle y carreras de día. Deste no dejar verse y desearlo muchos crecieron las alhajas de las terceras, que prometieron mostrarse primas y únicas en solicitar a Isabela; y no faltó quien se quiso aprovechar de lo que llaman hechizos, que no son sino embustes y disparates. Pero a todo esto estaba Isabela como roca en mitad del mar, que la tocan, pero no la mueven las olas ni los vientos.
\end{abstract}

Isabela se guarda gracias a su voluntad de hierro y a la lealtad de su amor, pero no gracias a la «seguridad» que la populosa ciudad proporciona o debería proporcionar, como creía la dama de Las dos doncellas. Ella se guarda a sí misma; no en virtud de la confusión de la ciudad.

Algo muy semejante sucede en El celoso extremeño, donde el secreto se descubre en virtud de los mismos pisaverdes de barrio: "hay en Sevilla un género de gente ociosa y holgazana, a quien comúnmente suelen llamar gente de barrio. Éstos son los hijos de vecino de cada colación, y de los más ricos della; gente baldía, atildada y meliflua, de la cual y de su traje y manera de vivir, de su condición y de las leyes que guardan entre sí, había mucho que decir; pero por buenos respectos se deja».

La novela se atiene al propósito medular, visto desde el espacio sevillano, de presentar a Loaysa como miembro de un grupo de gente ociosa y peligrosa para la honra de los demás sevillanos, que, de manera lógica, a causa de su curiosidad ociosa, se ve atraído por el hecho llamativo de que la casa del viejo celoso siempre está cerrada, nunca se abre y no tiene ventanas. Hace indagaciones, averigua la causa del enclaustramiento, conoce la hermosura de Leonora, y, en consecuencia, todo ello «le encendió el deseo de ver si sería posible expunar, por fuerza o por industria, fortaleza tan guardada». O, en términos de la edición Bosarte, es decir, de la primera versión: «le puso gana de ver si sería posible de expugnar tan guardada fuerza y dar un asalto a las murallas tan defendidas de Isabela». El sentido de la decisión es el mismo, como puede verse, aunque las palabras de la versión del manuscrito Porras se refieren con mayor rotundidad todavía al tópico de la torre amurallada, es decir, a la habitual forma literaria tradicional y caballeresca del encierro de la mujer; razón por la cual quizá el narrador ajustó más los términos de su 
alusión al revisar el texto, para no ser reiterativo en la mención de tan manido lugar común.

El celoso extremeño, en fin, nos ofrece, por una parte, el mismo anverso, con variaciones muy importantes, de La española inglesa, y el reverso de la Sevilla de Rinconete y Cortadillo, ya que aparece la Casa de Contratación y el monopolio comercial con las Indias, con sus ricos financieros y mercaderes. En ese ámbito de dinero y transacciones económicas se establece un viejo y rico indiano, Carrizales, por su calidad de puerto comercial de las Españas, de centro de salida y llegada para las Indias. Sin embargo, lo más curioso es que, de modo semejante a Rinconete, por otra parte, nos ofrece simultáneamente el reverso, dado que también en este ámbito oficial, público y rico de los mercaderes sevillanos y el comercio con América se oculta y encierra un secreto, se vela un mundo autónomo y cerrado dentro de la gran ciudad, ya que el viejo celoso se hace una casa fortaleza, sin ventanas y con una sola puerta para encerrar en ella a su joven esposa, sin otros varones, ni animales machos vivos o pintados que, como es lógico, llama de inmediato la atención de los sevillanos ociosos, de la «gente de barrio», porque no es Sevilla precisamente, la gran urbe de la época, el espacio más indicado para construir un encierro y aislarse en él, como quiere el anciano y celoso perulero, que por eso, entre otras cosas, fracasa.

Lope de Vega decía en una comedia sevillana, en La niña de plata, que la mujer enamorada solía ocultarse, para preservar la honestidad y la intimidad de su amor, mientras que la que no tenía amores, al contrario, se dejaba ver en público, con el fin de no cerrar su puerta, lo que parece lógico, y más desde las convenciones sociales y morales seiscentistas:

Principios son de olvidar
dejarse en público ver;
que esconderse una mujer
es alta señal de amar.

Pero en la Sevilla de Cervantes, aunque sucede así, origina resultados opuestos, como hemos visto, y la enamorada Isabela se ve rodeada, aunque a su pesar, de moscones que no le permiten pasar inadvertida, como es su deseo, mientras que la desenamorada y malcasada Leonora, ávida de otras miradas, se ve obligada al encierro por su celoso marido, lo que finalmente atrae asimismo un competidor.

Los extremos, en consecuencia, se tocan; los opuestos, se equilibran; la realidad se invierte, da otra vuelta de tuerca, y se ve al mismo tiempo por el haz y por el envés, todo a la par, según la mirada: unos personajes se oponen a otros dentro de la misma novela, pero los de otras novelas complementan, en paralelo, a unos, y se oponen, por diferencia, a otros; o ambas cosas a la vez. Y estos a los de otras novelas. Y así sucesivamente, en un conjunto que alcanza su sentido cabal únicamente analizado de esta manera, visto como una obra completa, unitaria, como un entrelazado magnífico de unas obras 
con otras, de unos personajes con otros, dentro y fuera de la misma novela, dentro y fuera de los diversos géneros literarios tocados por autor.

Y, lo que ahora me ocupa y me interesa más: todas las novelas —y escritos- que coinciden en el espacio sevillano, por concretar, alcanzan su sentido literario pleno y verdadero únicamente leídas desde ese espacio, vistas desde él, entendidas desde esas claves espaciales. Así, sin duda, el mismo espacio, el mismo ámbito, el mismo lugar es imprescindible: y Sevilla, en particular, más que ningún otro espacio, seguramente, para la comprensión entera de la obra cervantina, aunque mi argumentación no saldrá de las Ejemplares.

Se trata, en fin, de espacios sabiamente literarios, de mundos que se abren o se cierran en los lugares menos indicados, de ámbitos aislados o secretos dentro de la gran ciudad, de la Sevilla pública y privada, de la luz y de las tinieblas, de los aristócratas, los financieros y los rufianes. Porque eso es lo interesante, que las novelas cortas cervantinas ofrecen todas las múltiples, complejas e incluso a veces contradictorias caras de Sevilla, espacio literario fundamental de su novelar, seguramente el más importante de todos, y otras muchas de diversos lugares de Andalucía, en conjunto el espacio más querido para su autor, más incluso que la propia Mancha quijotesca.

Como prueba del amor cervantino por Sevilla y Andalucía, es suficiente recordar que Cervantes, que al fin y al cabo era complutense, esto es, cuasi madrileño, o más madrileño que otra cosa, en el peor de los casos, y pese a ser Madrid su centro, y pese al amor que tenía a la ciudad - expreso con claridad en la despedida del Viaje del Parnaso: "Adiós Madrid, adiós su prado y fuentes/.../que hoy de mi patria y de mí mismo salgo»-. Pese a todo eso, en suma, lo cierto es que la villa y corte no aparece casi nunca en su obra literaria, y únicamente lo hace en la primera parte de La gitanilla, en una comedia, La entretenida y en dos entremeses, La guarda cuidadosa y El vizcaíno fingido. El dato habla por sí solo, pues realza todavía más el andalucismo o, por mejor decir, el sevillanismo cervantino, que también aparece con todo su esplendor, por si no fuera suficiente, en el Quijote ${ }^{27}$, en la comedia del Rufián dichoso y en el entremés del Rufián viudo.

En la mencionada comedia de santos, por cierto, el gracioso Lagartija, ya en Méjico, añora y recuerda a menudo no solo la picaresca, sino la libertad de su amada Sevilla:

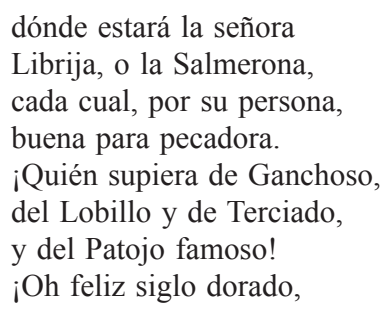

27. Como puede comprobarse en la magnífica lección, impresa en este mismo volumen, de José Lara Garrido. 
tiempo alegre y venturoso,

adonde la libertad

brindaba a la voluntad

del gusto más esquisito! (vv. 1359-1370)

Lope de Vega afirmaba asimismo la libertad como rasgo definitorio de Sevilla:

\author{
¡Pardiez, vamos a Sevilla! \\ FÉlix: ¡Oh, qué famosa ciudad! \\ CARRIZO: Y de mayor libertad \\ que las que tiene Castilla, \\ porque la gran confusión \\ de grandeza y forasteros, \\ de naves y de extranjeros, \\ causa de tenerla son. \\ Es bellísima en extremo. \\ (La buena guarda, II)
}

Y no hay duda de que este rasgo central de la urbe, su libertad, fue uno de los que más atrajo a nuestro autor, que siempre la defendió en su vida y en su obra, haciendo en una y afirmando en otra, como es bien sabido, que por la libertad «se puede y aun se debe aventurar la vida». La libertad, principio medular del vivir y del crear cervantinos ${ }^{28}$, y clave asimismo de la «famosa» y «bellísima en extremo» ciudad, hubo de ser uno de los principales nexos de unión entre la urbe y el escritor.

Cervantes asoció seguramente la libertad vital de la ciudad con la libertad de su quehacer literario, pues no en vano la aristocracia de sangre y la de las letras vivían en Sevilla aisladas, en su propio mundo, al margen la una de la otra. Como ha visto bien Márquez Villanueva: «Sevilla [...] no era sus palacios, sus universidades ni sus Gradas (anticipo de su lonja de mercaderes), sino el hervidero de sus plazas y del Arenal inmortalizado por Lope, donde se entrecruzan y van a lo suyo gentes de toda condición ${ }^{29}$. Cervantes, en consecuencia, ve gestarse en la ciudad del Guadalquivir un mundo nuevo, de fuerzas sociales y morales antes inexistentes, un mundo en ebullición, que surge en ese momento frente a las viejas estructuras, al margen de ellas o a su pesar, y que necesita, claro está, una nueva poética, una nueva forma de expresión capaz de dar cuenta de sus innovaciones nacientes. Nace así, simultáneamente, fruto en parte de esta experiencia biográfica sevillana, lo que yo he llamado la poética cervantina de la libertad. «Las estructuras autoritarias y jerárquicas de Sevilla quedan desbordadas e impotentes ante un fenómeno humano donde caóticamente hierve ya el futuro. El Arenal (como la plaza del Salvador o el Matadero) es ingobernable, lo mismo que ha de ser pura flexibilidad aventure-

28. Me he ocupado de esta cuestión por extenso en Poética de la libertad y otras claves cervantinas, Madrid, Eneida, 2005.

29. Art. cit., p. 146. 
ra y antidogmática $\aleph^{30}$. Dicha ingobernabilidad, más que patente en Rinconete, implica, como bien ha visto el maestro sevillano, libertad y antidogmatismo, sin duda, pero también aventura, y la aventura es una clave de la literatura cervantina indisolublemente unida a la libertad.

$\mathrm{Y}$ es que Sevilla era, asimismo, el espacio idóneo para la aventura, como dice tantas veces Lope de Vega en sus comedias, y como afirma expresamente Cervantes en el Quijote de 1605: "Lo mesmo hicieron Vivaldo y su compañero, y don Quijote se despidió de sus huéspedes y de los caminantes, los cuales le rogaron se viniese con ellos a Sevilla, por ser lugar tan acomodado a hallar aventuras, que en cada calle y tras cada esquina se ofrecen más que en otro alguno» (I, 14).

Era la aventura urbana, sin duda, la de las calles y plazas de la hermosa ciudad, la de los personajes de sus novelas cortas; pero no era ni podía ser la aventura de don Quijote, que necesitaba el campo abierto y los caminos despejados, sin corchetes ni policías que estorbasen su deambular. Por eso, quizá, no fue Sevilla espacio quijotesco, porque alguien tan loco y estrafalario como nuestro héroe, que no acepta la justicia legal de su época, hubiera chocado de inmediato con los alguaciles de la ciudad y hubiera acabado con sus huesos en la cárcel, como de hecho está a punto de sucederle al falso Quijote de Avellaneda en Madrid y le sucede en Zaragoza. La ciudad, cualquier ciudad, no era ni podía ser su espacio verosímil ${ }^{31}$.

Sevilla, en fin, como ya he adelantado, era para Cervantes un compendio del universo, una cifra del mundo, con toda la rica y compleja variedad, multiplicidad y diversidad que ofrecía la abigarrada sociedad contemporánea, tal y como afirmaba también Lope de Vega en términos inequívocos: «Un mundo en cifra retrata»; «Hase cifrado Sevilla/como todo el mundo en mapa» (Lope, El arenal de Sevilla, I, v. 40, y II, vv. 635-6). A la vez, libre y opresivo, abierto y cerrado, noble y villano, justo y e injusto, caballeresco y rufianesco, leal y traidor, casto y sexual; un espacio contradictorio y paradójico, en suma, peligroso y atractivo a la vez, como la vida misma; pero, eso sí, un ámbito en pequeño, abarcable, analizable, mensurable, visible para el lector. Eso es, más que ninguna otra ciudad, Sevilla en la obra de Cervantes, a la que podríamos resumir, acudiendo a lo más destacable de todo, a mi entender, como el ámbito libre que guarda secretos ocultos, el mundo abierto en que hay ciudades, países extraños, fronteras ajenas, justicias dispares, religiones encontradas, éticas paradójicas, e incluso, marca fronteriza indiscutible, lenguas diferentes, idiomas distintos, donde hasta hay que pagar impuestos para robar.

$\mathrm{O}$ si se quiere, y visto de otra manera, con palabras de Pedro Piñero y Rogelio Reyes:

Sevilla será un espacio determinante en su concepción de algunas de las Novelas ejemplares, en las que Cervantes crea un modelo de relato urbano

30. En palabras de Francisco Márquez Villanueva, ibíd., p. 147.

31. Para todo lo referente al Quijote, como ya he dicho, véase el magnífico trabajo incluido en este volumen de José Lara Garrido. 
que no podría entenderse sin su conocimiento de una gran ciudad abierta y cosmopolita como era aquélla, escenario de tipos, lances y episodios enteramente nuevos, propios de un mundo que vivía en continua transformación y que el autor logra captar con sorprendente lucidez $z^{32}$.

\section{CERVANTES Y SEVILla: VIDA Y LiTERATURA}

Aunque es difícil saber con rigor cuál fue la verdadera experiencia sevillana de Cervantes, dada la parquedad documental, no hay duda de que su balance final fue muy positivo, en opinión de la mayor parte de los estudiosos, incluso para Márquez Villanueva, que tiene algunas objeciones sobre el particular, en virtud de los escasos recuerdos posteriores a su estancia en la ciudad. Con todo, le parece «obvio, a pesar de todo, que Cervantes guardó siempre un recuerdo grato y hasta agradecido de sus años de hispalense adoptivo, a los que ciertamente debía mucho más que un hatajo de miserias y malos recuerdos. Nadie ha puesto nunca en duda que sin los agitados y nada gloriosos años de Sevilla no hubiera sido nunca el escritor que llegó a ser» ${ }^{33}$.

Cervantes sí volvió a acordarse de Sevilla, a lo que creo, y muy a menudo, como demuestran sus novelas cortas, escritas todas ellas después de su estancia en la ciudad y en algún caso casi podríamos decir que como verdadero homenaje a la misma, dado su papel destacado, casi de protagonista. En torno a 1604-1606, ya en Valladolid o en Madrid, sin ir más lejos, escribió las dos más hondamente sevillanas: Rinconete y El celoso extremeño, aunque solo en su primera redacción, realizada para la antología que Francisco Porras de la Cámara ofreció, por esas fechas, al cardenal de Sevilla, don Fernando Niño de Guevara, a mayor abundamiento de sevillanismo. Porque volvió a acordarse de nuevo años más tarde, al revisarlas por completo poco antes de 1612, como es sabido. Las dos doncellas, por su semejanza con el segundo Quijote en el elogio de Barcelona, debe de ser asimismo de las últimas del volumen, y también es muy sevillana, como hemos visto. En fin, no merece la pena insistir, porque el sevillanismo literario de Cervantes es obvio y permanece hasta su muerte.

Otra cosa es la vida, la experiencia biográfica. Su estancia en la ciudad del Guadalquivir estuvo llena de altibajos, pues tuvo momentos aceptables, si no boyantes, y vivió con cierta holgura en la posada de Tomás Gutiérrez, que le parece a Márquez un «hostal elegante», con un obvio buen pasar. Los altibajos económicos que se observan en Sevilla le parecieron a Astrana Marín obra del juego, del carácter de jugador empedernido que tenía Cervantes, pero quién sabe si fue así o hubo otras motivaciones. En cualquier caso, sí sabemos que Cervantes fue fiador de un subarriendo de casas en la colación de la Magdalena, de la que se dice vecino, a favor de una mujer llamada

32. Itinerarios de la Sevilla de Cervantes, p. 24.

33. Art. cit., p. 136 
Jerónima de Alarcón, posiblemente soltera, lo que indica una más que probable relación amorosa. Vivió, pues; amó, sufrió, jugó, negoció, trabajó, tuvo momentos buenos y malos, como tantos otros sevillanos de adopción; pero, sobre todo, observó, miró con atención, penetró incluso en las honduras más veladas y secretas de Sevilla. Y eso es lo que más nos interesa. Su mirada literaria sin par.

También sabemos que «negociaba con cuanto se le ponía a tiro», como prueba un documento de las mismas fechas del que le relaciona con Jerónima de Alarcón, de junio de 1589, para ser más preciso, en el que da poder a su ayudante, Miguel de Santa María, para cobrar en su ausencia «todos los maravedís y ducados y joyas, ropas, mercaderías, esclavos, vinos, aceites y gallinas y otras cosas de cualesquiera cantidades y calidades que se me deben hasta hoy y debieren de aquí en adelante en esta ciudad de Sevilla y en otras partes». Y este documento me inquieta bastante más. Por eso he subrayado en él la palabra esclavos. Porque el campeón de la libertad, el defensor apasionado de la libertad política, de la mujer, de los oprimidos, de la libertad contra el destino, etc., el autor de lo que he llamado insistentemente poética de la libertad, comercia o acepta comerciar con esclavos. ¿Hay mayor contradicción? Desde luego, parece difícil encontrar una contradicción más grande. Y sin embargo, en términos exactamente cervantinos, no debería haberla, pese a todo, porque para Cervantes una cosa es la vida y otra completamente ajena la literatura, aunque el problema, como he insistido tantas veces, era que los lectores interpretaban la literatura como vida y desde la vida, confundiéndola con ella. Recordaré simplemente unas palabras significativas de El curioso impertinente:

- Luego, ¿todo aquello que los poetas enamorados dicen es verdad?

- En cuanto poetas no la dicen — respondió Lotario-; mas, en cuanto enamorados, siempre quedan tan cortos como verdaderos.

— No hay duda deso — replicó Anselmo. (I, 24)

Una cosa es la vida real y otra la literatura. Las necesidades perentorias de la una no son equiparables a las de la otra. Cervantes vivió como pudo y escribió como los ángeles. Su estancia en Sevilla es buena prueba de estas contradicciones. La biografía y la escritura caminan juntas y son indudablemente relacionables, pero no solidarias ni equiparables en sentido estricto. Una cosa es el poeta como tal, y otra completamente distinta el hombre enamorado, aunque el poeta escriba sobre el amor y desde el enamoramiento. Cervantes lo expresó con una modernidad literaria impar, aunque pueda ponerse en entredicho la moralidad de su vida, pero lo dijo, en cualquier caso, con claridad, rotundidad y acierto estético casi increíble, doscientos cincuenta o sesenta años antes que Bécquer, otro sevillano de pro, dicho sea de paso.

La cita del gran poeta decimonónico me sirve para volver a la relación meramente biográfica de Cervantes con su bella y querida ciudad del Betis, porque Márquez Villanueva lo agrupa con nuestro autor por su común olvido 
de la urbe andaluza: «En Sevilla - escribe don Francisco- el poeta ha de nadar siempre solo y contra la marea, hasta el momento en que se adocena, enmudece o la abandona, que es lo que hizo Cervantes, pero también Mateo Alemán, Blanco White, Bécquer, los Machado, Juan Ramón y Cernuda. La vida sevillana y su introversión indiferente a nada exterior a sí misma, puede volverse opresora y abocarse a un momento en que con toda claridad se perfile la necesidad de buscar otros horizontes $\rangle^{34}$.

Márquez cree que «lo que claramente no ha tenido Cervantes en Sevilla es ninguna intensa actividad literaria. Inútil pedir lo imposible y tampoco nada en esto que lamentar» ${ }^{35}$. Sin embargo, Rodríguez Marín aseguraba que había sido mucha su actividad creadora, y afirmaba que Rinconete y el Celoso se escribieron en Sevilla. No lo sabemos con certeza, pero es muy posible que así fuera, y si no, como el Quijote, no hay duda de que todas estas novelas se engendraron en Sevilla, en el peor de los casos, y de que Cervantes las escribió llevando a la bella ciudad en el corazón. Es verdad que nuestro novelista no participó a menudo en los círculos literarios más célebres y selectos de la urbe, y sí lo hizo, en cambio, en la llamada Academia de Ochoa, que reunía a un grupo de poetas marginales en algún bodegón, y en la que figuraban, como descubrió Rodríguez Marín, Juan de Ochoa, Juan López del Valle, Alonso Álvarez de Soria y Luis Vélez de Guevara, con quien, dicho sea de paso, siempre mantuvo la amistad Cervantes, y a quien definió como a sí mismo, esto es, como poeta alegre, como «regocijo de las musas». Quizá convendría recordar aquí que Vélez fue un poeta y dramaturgo cortesano, al servicio del conde de Saldaña en Madrid y Valladolid, esto es, lejos de todo marginalismo, para evitar malentendidos. No obstante, y volviendo a Cervantes, aunque es verdad que no asistió nunca a las reuniones de, por ejemplo, el segundo marqués de Tarifa, don Fernando Enríquez de Ribera, discípulo de Francisco de Medina, no es cierto que participara únicamente de las tertulias de los marginales, dado que sí buscó el amparo de los poderosos, en concreto del inteligente Porras de la Cámara y del propio cardenal arzobispo de Sevilla, don Fernando Niño de Guevara, a quien ofreció dos de sus más bellas primicias novelescas. De modo que de marginalismo, al menos voluntario, nada de nada.

Cervantes, a lo que entiendo, no dejó Sevilla porque la ciudad diera de lado las letras, ni por su alejamiento personal de los círculos de la aristocracia, ni por su soledad de escritor, sino llevado por las circunstancias de su azarosa vida. No hay nunca encono ni desdén hacia Sevilla, sino todo lo contrario, amor, interés y pasión por su abigarramiento desbordado, su vida a raudales, su complejidad, su libertad y su belleza. En esto estoy al lado de Rogelio Reyes, cuyas palabras suscribo, y para quien no hay:

[...] suficientes elementos de juicio que permitan atribuir su marcha de la ciudad a otros motivos diferentes a los simples azares y circunstancias de

34. Art. cit., p. 148

35. Ibíd., p. 136. 
la vida, que tanto zarandearon por cierto al gran escritor. No termino por ello de ver a Cervantes como un voluntario exiliado de la ciudad que al marcharse "sacudió para siempre de sus sandalias el polvo de Sevilla», subrayando así, por consiguiente, tal como dice el texto evangélico, la culpabilidad de lo que se dejaba atrás. [...] Se trata, en mi opinión, de situaciones muy diferentes entre $\mathrm{si}^{36}$ que no pueden medirse por el mismo rasero y mucho menos interpretarse como hitos de una misma secuencia moral en la relación entre la ciudad y sus escritores. [...] Es poco en verdad lo que documentalmente sabemos del balance íntimo que Cervantes pudo haber hecho de Sevilla cuando salió de ella, quizá para siempre, en los umbrales del siglo XVII, y sobre todo de cuáles fueron los verdaderos motivos que le impulsaron a dejarla. Pero en sus escritos no parece evidenciarse ningún desagrado de índole personal. Ningún indicio de resentimiento interior que pueda ir más allá de sus críticas de los aspectos morales y sociales de la ciudad en su conjunto ${ }^{37}$.

Recibido: 14-05-2009

Aceptado: 27-07-2009

\title{
Resumen
}

El artículo analiza la imbricación de vida y literatura que las Novelas Ejemplares de Cervantes - o, para ser más preciso, algunas de ellas - llevan como un sello principal de su identidad artística; sello que implica, a su vez, una determinada visión de Andalucía, en general, y sobre todo de Sevilla, en particular: de una Sevilla que es a la vez objeto e inspiración de una peculiar mirada novelesca, necesaria para entender tanto algunas de estas novelas como la percepción literaria del espacio que hay en la obra de Cervantes.

Palabras clave: Cervantes. Andalucía. Sevilla. Espacio novelesco. Espacio real. Vida. Literatura. Novelas ejemplares.

Title: Andalusia in Cervantes' Novelas Ejemplares: a reflection in Cervantes' literary space

\begin{abstract}
The article analyses the interrelationship between life and literature which Cervantes' Novelas Ejemplares —or to be more precise, some of them - bear as a hallmark of their artistic identity; a hallmark which in turn involves a certain view on Andalusia, and above all, on Seville; particularly, on a Seville which stands for both the object of and the inspiration to a peculiar novelistic view which is key for understanding some of these novels and the spatial literary perception we find in Cervantes' oeuvre.
\end{abstract}

Key words: Cervantes. Andalusia. Seville. Literary space. Real space. Life. Literature. Exemplary novels.

36. Se refiere a las de las de Mateo Alemán, Blanco White, Bécquer, los Machado, Juan Ramón y Cernuda, que mencionaba Márquez Villanueva.

37. "Cervantes y Sevilla: historia de una relación humana y literaria», en Don Quijote en el reino de la fantasía, Fundación Focus Abengoa, Sevilla, 2004, pp. 46-47. 